\title{
EFFECTS OF ENVIRONMENTAL CONDITIONS ON PROPANIL DEGRADING ACTIVITY OF Acinetobacter baumannii DT
}

\author{
Dau Thi Hong Ngoc ${ }^{1}$, Ha Danh Duc ${ }^{2, *}$, Nguyen Thi Dieu Thuy ${ }^{1}$ \\ ${ }^{1}$ Institute of Biotechnology, VAST, Vietnam \\ ${ }^{2}$ Dong Thap University, Dong Thap Province, Vietnam \\ Received 14 January 2020, accepted 28 July 2020
}

\begin{abstract}
Effects of various environmental conditions on propanil degrading activity of Acinetobacter baumannii DT were investigated. Results showed that both propanil degradation and bacterial growth rate were reduced when bacteria were cultured in extreme conditions, such as high acidic or alkaline levels or high salinity. Moreover, the propanil degradation activity of A. baumannii DT decreased in contaminated water. The propanil dissipation rate was higher in herbicidescontaminated soil (treated soil) than in herbicide-free soil. In soil inoculated with A. baumannii DT, propanil removal was enhanced. Even though the propanil degrading activity of $A$. baumannii DT were reduced under extremely stressful conditions, this bacterium retained a good potential to degrade propanil in real environmental conditions.
\end{abstract}

Keywords: Acinetobacter baumannii DT, environmental factors, extreme conditions, propanil.

Citation: Dau Thi Hong Ngoc, Ha Danh Duc, Nguyen Thi Dieu Thuy, 2020. Effects of environmental conditions on propanil degrading activity of Acinetobacter baumannii DT. Academia Journal of Biology, 42(3): 111-118. https://doi.org/10.15625/2615-9023/v42n3.14781.

*Corresponding author email: hadanhduc@gmail.com

(C2020 Vietnam Academy of Science and Technology (VAST) 


\section{INTRODUCTION}

Pesticides have been intensively applied in agriculture, which is an issue of global concern. Propanil has been extensively used to control grasses and sedges worldwide, including Vietnam. This post-emergence contact herbicide, which inhibits the photosynthesis process of broadleaf weeds (Tomlin, 2009), is usually applied to flooded paddy fields, corn fields and other fruit gardens. Therefore, propanil and its metabolites have been detected in surface water, groundwater and soil (Dabrowski et al., 2002; Silva et al., 2006; Primel et al., 2007). For example, propanil was detected to be up to $3.6 \mathrm{mg} / \mathrm{L}$ in irrigation water in Brazil (Primel et al., 2007).

Propanil has acute toxicity to a number of aquatic species (Pothuluri et al., 1991; Mitsou et al., 2006; Darren et al., 2009), leading to death from acute poisoning, especially methemoglobinemia (Darren et al., 2009). 3,4-dichloroaniline is a common major product of propanil transformation. This metabolite also causes adverse health and ecotoxicity effects (Salazar et al., 2008). Propanil and 3,4-dichloroaniline may enter natural aquatic systems, and reach water supply resources or accumulate in the soil, where the substrates are difficult to be biodegraded because of the environmental conditions unsuitable for microorganisms to degrade them.

Propanil may be degraded by physical, chemical and biological pathways. This compound can undergo chemical hydrolysis within a wide range of $\mathrm{pH}$ levels, and photodegraded under direct sunlight with a half-life of 12 hours (Dahchour et al., 1986). However, biodegradation is considered to be an effective and environmentally friendly method to remediate pesticides and other organic compounds. Several bacteria and fungi can transform propanil to 3,4-dichloroaniline; e.g., Fusarium oxysporum (Reichel et al., 1991), Paracoccus sp. FLN-7 (Zhang et al., 2012), Ochrobactrum sp. PP-2 (Zhang et al., 2019a) and Spirosoma sordidisoli TY50 ${ }^{\mathrm{T}}$ (Zhang et al., 2019b). However, these isolates require the addition of co-substrates for the biotransformation of propanil. They also can not degrade 3,4-dichloroaniline. Moreover, propanil may accumulate in extreme environments such as soils with high alkaline and acidic values, high salinity, and low oxygen content. However, most studies have been carried out in artificial media. Thus, evaluation of propanil biodegradation under extreme natural conditions should be conducted to investigate the possibility of biodegrading propanil and its delivatives at contaminated sites. In this study, the propanil degrading activity of $A$. baumannii DT isolated from soil (Oanh et al., 2020) was investigated under extreme conditions, in natural water and in soil.

\section{MATERIALS AND METHODS}

\section{Cultivation media and bacteria}

The mineral medium (MM medium) used was prepared according to Nguyen \& $\mathrm{Ha}$ (2019) consisting of $1,419.6 \mathrm{mg} / \mathrm{L} \mathrm{Na} 2 \mathrm{HPO}_{4}$, $1,360.9 \mathrm{mg} / \mathrm{L} \quad \mathrm{KH}_{2} \mathrm{PO}_{4}, 98.5 \mathrm{mg} / \mathrm{L} \quad \mathrm{MgCl}_{2}$, $5.88 \mathrm{mg} / \mathrm{L} \mathrm{CaCl} \cdot 2 \mathrm{H}_{2} \mathrm{O}, 8.4 \mathrm{mg} / \mathrm{L} \mathrm{NaHCO}_{3}$, $1.16 \mathrm{mg} / \mathrm{L} \mathrm{H}_{3} \mathrm{BO}_{4}, 1.15 \mathrm{mg} / \mathrm{L} \mathrm{ZnSO}{ }_{4} \cdot 7 \mathrm{H}_{2} \mathrm{O}$, $0.38 \mathrm{mg} / \mathrm{L} \quad \mathrm{CuSO}_{4} \cdot 5 \mathrm{H}_{2} \mathrm{O}$, and $0.24 \mathrm{mg} / \mathrm{L}$ $\mathrm{CoCl}_{2} \cdot 6 \mathrm{H}_{2} \mathrm{O}, 1.0 \mathrm{~g} / \mathrm{L}\left(\mathrm{NH}_{4}\right)_{2} \mathrm{SO}_{4}$ and $1.0 \mathrm{~g} / \mathrm{L}$ succinate. $\mathrm{pH}$ was adjusted to 7.0. The medium was sterilized at $121{ }^{\circ} \mathrm{C}$ for $15 \mathrm{~min}$ before use. Propanil (99.6\%) and other chemicals were purchased from SigmaAldrich (Singapore) and Merck (Germany).

The Acinetobacter baumannii DT isolate used in this study has been proven to degrade propanil and 3,4-dichloroaniline effectively under laboratory conditions (Oanh et al., 2020). The $16 \mathrm{~S}$ rRNA sequence of this isolate has been deposited in GenBank and available in NCBI under the accession number MN658561.1.

\section{Evaluation of propanil degradation under various conditions}

Bacteria cultured in Luria-Bertani (LB) medium for 12 hours were used for inoculation. Propanil degradation was carried out in $150 \mathrm{~mL}$-bottles containing $40 \mathrm{~mL}$ of the MM medium. $0.1 \mathrm{~mL}$ of the inoculum was 
transferred to the MM medium to provide an initial bacteria concentration of $10^{6} \mathrm{CFU} / \mathrm{mL}$, except for studying the effects of cell numbers on the degradation, in which the initial inoculum ranged from $10^{5}$ to $10^{8} \mathrm{CFU} / \mathrm{mL}$.

For the effects of $\mathrm{pH}$ values on degradation, $\mathrm{NaOH}(10 \mathrm{M})$ and $\mathrm{HCl}(5 \mathrm{M})$ were used to adjust $\mathrm{pH}$ levels. In another experiment, $\mathrm{NaCl}$ was added at the dose range of $1.0-5.0 \%$ to determine the effects of salinity on propanil degradation and bacterial growth.

For the effects of oxygen levels on bacterial activities, experiments with oxygen restriction in anoxic media were carried out using bottles sealed with rubber septa and aluminum crimps during the incubation processes. The anaerobic condition was created by bubbling nitrogen gas into the bottles for $20 \mathrm{~min}$. Rezasurin $(0.4 \mathrm{mM})$ was used as an indicator to confirm the anaerobic condition. Liquid samples were collected from bottles to determine the degradation during incubation process using syringes and needles. Bacteria activities under normal conditions were determined in bottles capped with cotton plugs. The cap was opened when collecting liquid samples.

To evaluate the propanil degradation in relatively clean natural water, water samples were collected from the Tien River (a branch of the Mekong River) at Cao Lanh City. Additionally, contaminated water was collected from a trench in a fruit garden in Lap Vo District, Dong Thap Province, where farmers have been using herbicides including propanil to kill grasses. The chemical components of those water samples were analyzed according to the APHA method (APHA, 1998).

All experiments were performed at least three replicates. Incubation was conducted at $30{ }^{\circ} \mathrm{C}$ with a rotation speed of $150 \mathrm{rpm}$. Propanil was added at $0.1 \mathrm{mM}$. Degradation in abiotic controls was also measured to compare with degradation by A. baumannii DT.

\section{Propanil degradation in soil}

One soil sample was collected from a depth of $10-50 \mathrm{~cm}$ in a corn field where farmers have been using herbicides occasionally (contaminated soil). Another soil sample was collected from mountain named Nui Cam, An Giang Province, where no herbicide has been used (uncontaminated soil). The soil samples were broken up, crumbled, then sieved through a mesh with 2 $\mathrm{mm}$ in diameter. Soil components were determined according to the soil texture triangle (Soil Science Division Staff, 2017). Other physicochemical properties were analyzed using the APHA method (1998).

The bacteria inoculation and propanil degradation in soil were conducted as described by Duc (2017). The propanil degradation was also determined in soil without inoculation. Propanil in soil was extracted with acetone as described by Milan et al. (2012). The extraction efficiencies of propanil from contaminated and uncontaminated soil were $92.0 \%$ and $94.6 \%$, respectively.

\section{Analytical methods}

Bacteria numbers in liquid media were counted based on colony-forming units (CFU) on LB agar plates. Propanil concentrations were measured using reversed-phase highperformance liquid chromatography (HPLC) as described in a previous study (Oanh et al., 2020). The HPLC profiles were compared with standards to obtain the results.

\section{RESULTS AND DISCUSSION}

\section{Effects of pH levels on propanil degradation}

Propanil degradation by A. baumannii DT and its growth on the substrate at various $\mathrm{pH}$ levels revealed that the optimum $\mathrm{pH}$ was 7.0 (Fig. 1). The degradation rates decreased in acidic and alkaline conditions. The overall biodegradation rate was proportional to the bacteria growth in both acidic and acidic conditions, suggesting that biodegradation capacity of individual bacterium is maintained well at wide ranges of $\mathrm{pH}$, with the range of acidic $\mathrm{pH}$ being wider. 

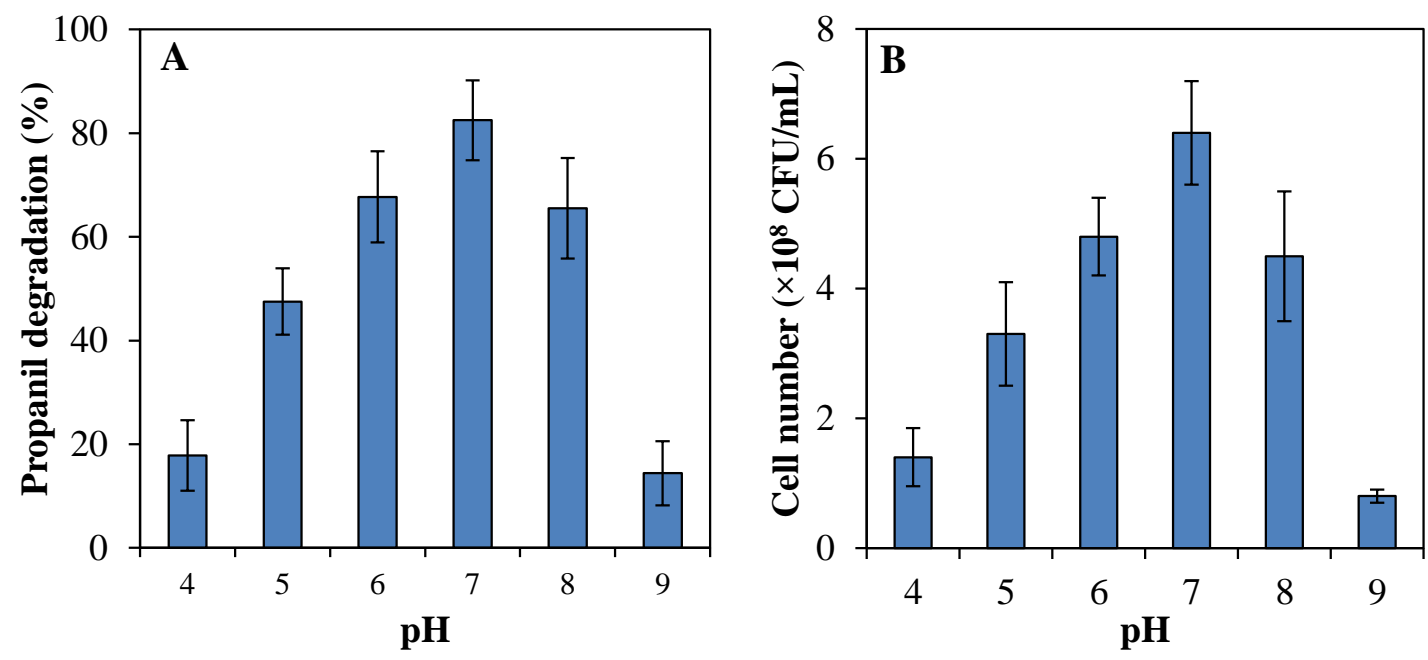

Figure 1. Effects of $\mathrm{pH}$ on propanil degradation (A) and bacterial growth (B) of $A$. baumannii DT for 10 hours at $0.1 \mathrm{mM}$ propanil

Effects of salinity on propanil degradation and bacterial growth

When applied to soil, propanil may contaminate water. The contaminated water will flow to brackish zones and eventually into marine water. Thus, determining the acceptable range of $\mathrm{NaCl}$ concentrations for
A. baumannii DT to degrade propanil is critical for field application of this bacterium. Results showed that no significant differences in degradation and growth rates were observed within the range of $0-2 \% \mathrm{NaCl}$. However, degradation and growth decreased with the dose at $\mathrm{NaCl}$ concentrations $>2 \%$ (Fig. 2).
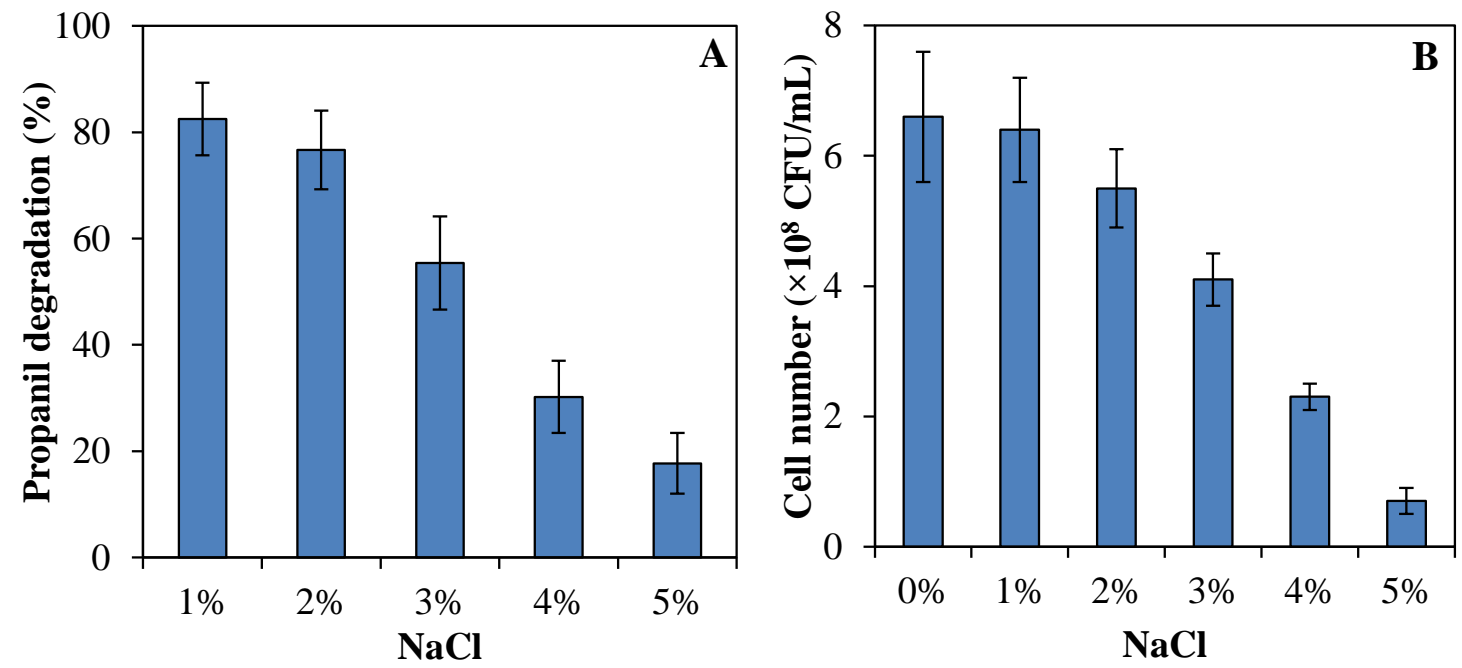

Figure 2. Effects of salinity on propanil degradation (A) and bacterial growth rates (B) of A. baumannii DT at $0.1 \mathrm{mM}$ propanil for 10 hours

Effects of $A$. baumannii DT inoculum concentrations on the efficacy of propanil degradation
Increasing bacterial cell concentrations enhanced the propanil degradation rate. An initial inoculation dose of $10^{8} \mathrm{CFU} / \mathrm{mL}$ 
resulted in complete degradation of $0.1 \mathrm{mM}$ propanil within 10 hours. At lower initial inoculum concentrations, the degradation rates were slower (Fig. 3). However, propanil degradation was mostly complete by 15 hours regardless of initial incubation doses.

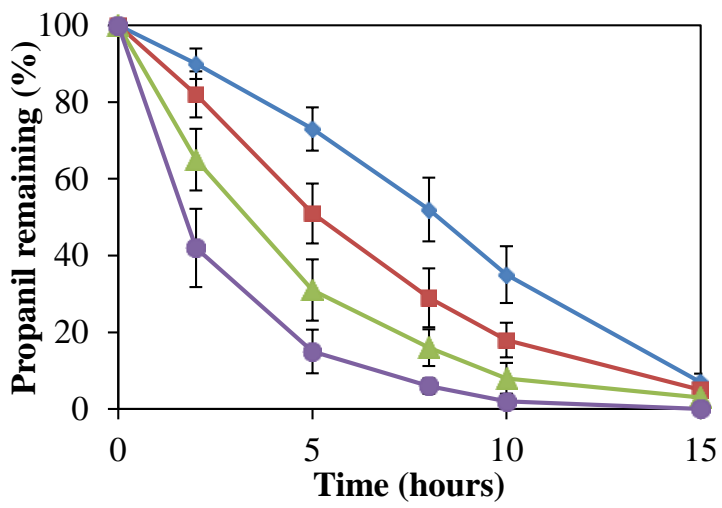

Figure 3. Effects of initial inoculation dose of A. baumannii DT on propanil degradation at $0.1 \mathrm{mM}$ propanil. The initial bacteria concentration $(\mathrm{CFU} / \mathrm{mL})$ were $10^{8}$ (circle symbol), $10^{7}$ (trangle symbol), $10^{6}$ (square symbol) and $10^{5}$ (diamond symbol)

Effects of oxygen concentrations on propanil degradation and bacterial growth

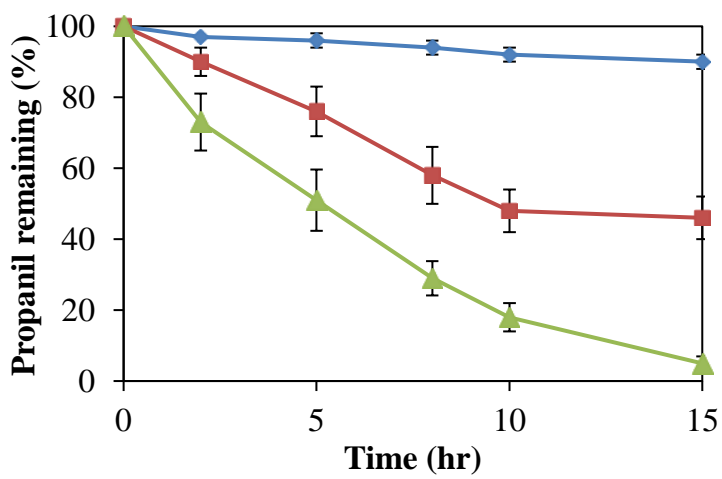

Figure 4. Effects of oxygen on propanil degradation at $0.1 \mathrm{mM}$. The degradation was

performed at normal (triangle symbol), restricted oxygen (square symbol) and anoxic (diamond symbol) conditions

Propanil may contaminate soil and sediment where the oxygen is restricted. The evaluation of propanil degradation by $A$. baumannii DT in anoxic and anaerobic condition will provide useful information about the application of bacteria for propanil remediation in soil and sediment. Propanil degradation was initially normal but markedly decreased with time under anaerobic conditions (Fig. 4). The degradation was slow under limited oxygen condition with no progress after the first 10 hours, probably due to oxygen in the medium being exhausted. These results suggest that $A$. baumannii DT can degradade propanil effectively only under an aerobic condition.

\section{Propanil degradation by $A$. baumannii DT in environmental water collected from the river and the contaminated trench}

As shown in table 1, water collected from the Tien River was quite clean, while trench water was of poor quality regarding total suspended solids, total nitrogen, chemical oxygen demand (COD) and bacteria numbers. However, propanil was not detected in both water sources.

Then, propanil degradation by $A$. baumannii DT was performed in two extremely different water samples, river water and trench water. Figure 5 showed that the degradation by indigenous microorganisms in two types of water samples was not significant. Even though adding ammonium sulfate and succinate as supplemental nutrients increased the degradation process, the degradation rates of $A$. baumannii DT in natural water were significantly lower compared to the rates in MM medium shown in Fig. 3.

Propanil degradation by A. baumannii DT in sterile and non-sterile river water was mostly comparable. Propanil degradation by A. baumannii DT in non-sterile trench water was significantly lower than that in the sterile one. Moreover, regardless of the experimental conditions, propanil degradation in trench water was always slower than in the river water. These results suggest that high numbers of native microorganisms and higher $\mathrm{pH}$ levels of the trench water might confer inhibitory effects on propanil degradation of A. baumannii DT. 
Dau Thi Hong Ngoc et al.

Table 1. Chemical components of water samples collected from the Tien River and a trench

\begin{tabular}{|l|c|c|c|}
\hline \multicolumn{1}{|c|}{ Parameters } & Unit & The Tien River water & Trench water \\
\hline $\mathrm{pH}$ & & 7.3 & 7.7 \\
\hline Total suspended solids & $\mathrm{mg} / \mathrm{L}$ & 70.2 & 217.7 \\
\hline Total nitrogen & $\mathrm{mg} / \mathrm{L}$ & 0.44 & 1.02 \\
\hline Total phosphorus & $\mathrm{mg} / \mathrm{L}$ & 0.06 & 0.09 \\
\hline Dissolved oxygen & $\mathrm{mg} / \mathrm{L}$ & 7.12 & 6.25 \\
\hline Chemical oxygen demand & $\mathrm{mg} / \mathrm{L}$ & 2.01 & 3.51 \\
\hline Propanil & $\mathrm{mg} / \mathrm{L}$ & 0.0 & 0.0 \\
\hline Sulfate & $\mathrm{mg} / \mathrm{L}$ & 5.6 & 7.1 \\
\hline Chloride & $\mathrm{mg} / \mathrm{L}$ & 6.8 & 7.3 \\
\hline Calcium & $\mathrm{mg} / \mathrm{L}$ & 7.1 & 6.1 \\
\hline Magnesium & $\mathrm{mg} / \mathrm{L}$ & 3.3 & 3.7 \\
\hline Sodium & $\mathrm{mg} / \mathrm{L}$ & 3.5 & 4.7 \\
\hline Potassium & $\mathrm{mg} / \mathrm{L}$ & 0.8 & 0.6 \\
\hline Bacteria & $\mathrm{CFU} / \mathrm{mL}$ & $3 \times 10^{5}$ & $7 \times 10^{6}$ \\
\hline
\end{tabular}
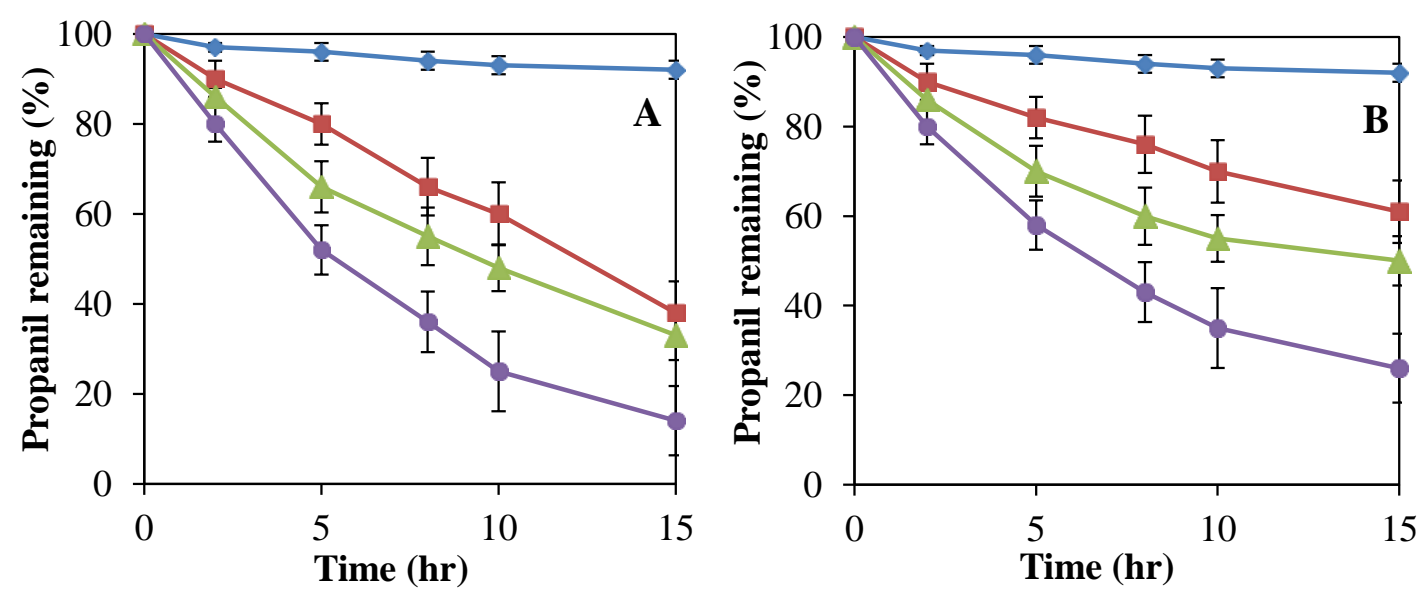

Figure 5. Degradation of propanil in water collected from the Tien River (A) and a trench in a fruit garden (B). The degradation was performed in non-sterile water without $A$. baumannii DT (diamond symbol), non-sterile water with $A$. baumannii DT (square symbol), sterile water with A. baumannii DT (triangle symbol), and sterile water with $A$. baumannii DT supplemented with $\left(\mathrm{NH}_{4}\right)_{2} \mathrm{SO}_{4}$ and succinate (circle symbol)

Effects of soil components on the propanil degradation in soil

Soil samples collected from two sites had different components (Table 2). Corn field soil (treated soil) contained higher concentrations of silt, clay, total organic carbon, nitrogen and phosphorus, while soil from the mountain (untreated soil) contained a higher amount of sand and other minerals. Propanil was not detected in both soil samples (Table 2).
Figure 6 showed that the propanil concentrations decreased in all treatments. Propanil dissipation was lowest in mountain soil. The highest degradation was found in corn field soil, in which most propanil disappeared after 10 days. Inoculating A. baumannii DT into soil enhanced the degradation rates. Previous studies also reported quick transformations of propanil in soil (Burge, 1972; Milan et al., 2012). Degradation in untreated soil was slower compared to in 
treated soil, probably due to the activities of treated soil were adapted to propanil and might native microorganisms. Microorganisms in also degrade the substrate.

Table 2. Chemical and physical properties of dried soil samples

\begin{tabular}{|l|c|c|}
\hline \multicolumn{1}{|c|}{ Parameter } & Soil collected from corn field & Soil collected from Nui Cam \\
\hline Sand $(\%)$ & $45.2 \pm 4.54$ & $60.8 \pm 6.06$ \\
\hline Silt $(\%)$ & $25.4 \pm 4.40$ & $26.6 \pm 4.52$ \\
\hline Clay $(\%)$ & $29.4 \pm 4.44$ & $12.7 \pm 3.36$ \\
\hline pH & $6.8 \pm 0.54$ & $6.6 \pm 0.36$ \\
\hline Total Organic Carbon $(\%)$ & $1.12 \pm 0.11$ & $0.76 \pm 0.06$ \\
\hline Nitrogen $(\%)$ & $0.096 \pm 0.01$ & $0.055 \pm 0.01$ \\
\hline Phosphorus $(\%)$ & $0.066 \pm 0.01$ & $0.097 \pm 0.01$ \\
\hline Potassium $(\%)$ & $0.018 \pm 0.00$ & $0.028 \pm 0.00$ \\
\hline Zink $(\mathrm{mg} / \mathrm{kg})$ & $0.55 \pm 0.03$ & $0.96 \pm 0.06$ \\
\hline Copper $(\mathrm{mg} / \mathrm{kg})$ & $0.56 \pm 0.07$ & $0.90 \pm 0.08$ \\
\hline Iron $(\mathrm{mg} / \mathrm{kg})$ & $9.4 \pm 0.10$ & $22.4 \pm 0.17$ \\
\hline Propanil $(\mathrm{mg} / \mathrm{kg})$ & 0 & 0 \\
\hline
\end{tabular}

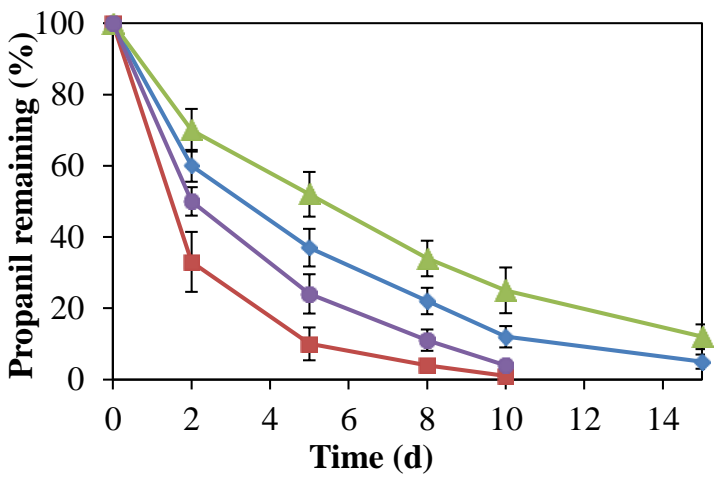

Figure 6. Propanil degradation in soil at 0.1 $\mathrm{mM} / \mathrm{kg}$ soil. The treatments consisted of untreated soil without bacteria inoculation (triangle symbol), treated soil with inoculation with $A$. baumannii DT (circle symbol), treated soil without bacteria inoculation (diamond symbol), and treated soil inoculated with $A$. baumannii DT (square symbol)

\section{CONCLUSION}

The effects of various environmental factors on the propanil degradation by $A$. baumannii DT were evaluated. Higher levels of acidity, alkalinity and salinity reduced bacterial activities. Degradation was also slower in contaminated water than in MM medium or clean river water. Inoculating this isolate into untreated and treated soils increased degradation. Although the degradation and growth of A. baumannii DT was affected by extreme environmental conditions, this bacterial strain showed a good potential for propanil degradation in real environmental conditions.

Acknowledgements: This research was supported by the project B2019.SPD.04 of Vietnamese Ministry of Education and Training. The authors would like to thank them for funding this study. Authors thank all who have provided supports.

\section{REFERENCES}

APHA, 1998. Standard methods for the examination of water and wastewater, 20th ed. American Public Health Association, Washington, DC.

Burge W. D., 1972. Microbial populations hydrolyzing propanil and accumulation of 3,4-dichloroaniline and 3,3',4,4'tetrachloroazobenzene in soils. Soil Bid. Biochem., 4: 379-386.

Dabrowski J. M., Peall S. K., Van Niekerk A., Reinecke A. J., Day J. A., Schulz R., 2002. Predicting runoff-induced pesticide input in agricultural sub-catchment surface waters: linking catchment variable 
Dau Thi Hong Ngoc et al.

sand contamination. Water Research, 36: 4975-4984.

Dahchour A., Bitton G., Coste C. M., Bastide J., 1986. Degradation of the herbicide propanil in distilled water. Bull. Environ. Contam. Toxicol., 36(4): 556-562.

Darren R., Renate H., Nick B., Andrew D., Mohamed F., Michael E., Peter E., 2009. Clinical outcomes and kinetics of propanil following acute self-poisoning: a prospective case series. BMC Clin. Pharmacol., 9: 3.

Duc H. D., 2017. Degradation of chlorotoluenes by Comamonas testosterone KT5. Appl. Biol. Chem., 60(4): 457-465.

Milan M., Vidotto F., Piano S., Negre M., Ferrero A., 2012. Dissipation of propanil and 3,4 dichloroaniline in three different rice management systems. $J$ Environ. Qual., 41(5): 1487-1496.

Mitsou K., Koulianou A., Lambropoulou D., Pappas P., Albanis T., Lekka M., 2006. Growth rate effects, responses of antioxidant enzymes and metabolic fate of the herbicide propanil in the aquatic plant Lemna minor. Chemosphere, 62: 275-284.

Nguyen O. T., Ha D. D., 2019. Degradation of chlorotoluenes and chlorobenzenes by the dual-species biofilm of Comamonas testosteroni strain KT5 and Bacillus subtilis strain DKT. Ann. Microbiol., 69: 267-277.

Oanh N. T., Duc H. D., Ngoc D. T. H, Thuy N. T. D., Hiep N. H., Hung N. V., 2020. Biodegradation of propanil by Acinetobacter baumannii DT in a biofilmbatch reactor and effects of butachlor on the degradation process. FEMS Microbiol. Lett., 367(2): fnaa005. https://doi.org/10.1093/femsle/fnaa005.

Pothuluri J., Hinson J., Cerniglia C., 1991. Propanil: toxicological characteristics, metabolism, and biodegradation potential in soil. J. Environ. Qual. (USA), 20: 330-347.

Primel E. G., Zanella R., Kruz M. H. S., Goncalves F. F., Martins M. L., Machado S. L. O., Marchesan E., 2007. Risk assessment of surface water contamination by herbicide residues: monitoring of propanil degradation in irrigated rice field waters using HPLC-UV and confirmation by GC-MS. J. Braz. Chem. Soc., 18(3): 585-589.

Reichel H., Sisler H., Kaufman D., 1991. Inducers, substrates, and inhibitors of a propanil-degrading amidase of Fusarium oxysporum. Pestic Biochem. Physiol., 39: $240-250$

Salazar K. D., Ustyugova I. V., Brundage K. M., Barnett J. B., Schafer R., 2008. A review of the immunotoxicity of the pesticide 3, 4-dichloropropionanalide. $J$. Toxicol Environ Health B Crit. Rev., 11: 630-645.

Silva E., Batista S., Viana P., Antunes P., Serôdio L., Cardoso A. T., Cerejeira M. J., 2006. Pesticides and nitrates in groundwater from oriziculture areas of the 'Baixo Sado' region (Portugal). Int. J. Environ. An. Ch., 86: 955-972.

Soil Science Division Staff, 2017. Soil survey manual. C. Ditzler, K. Scheffe, and H. C. Monger (eds.). USDA Handbook 18. Government Printing Office, Washington, D.C.

Tomlin C., 2009. The Pesticide Manual, Fifteenth. BCPC Publications, UK: 944-945.

Zhang J., Yin J. G., Hang B. J., Cai S., He J., Zhou S. G., Li S. P., 2012. Cloning of a novel arylamidase gene from Paracoccus sp. strain FLN-7 that hydrolyzes amide pesticides. Appl. Environ. Microbiol., 78: 4848-4855.

Zhang L., Hu Q., Hang P., Zhou X., Jiang J., 2019a. Characterization of an arylamidase from a newly isolated propanil-transforming strain of Ochrobactrum sp. PP-2. Ecotoxicol. Environ. Saf., 167: 122-129.

Zhang L., Zhou X. Y., Su X. J., Hu Q., Jiang J. D., 2019b. Spirosoma sordidisoli sp. nov., a propanil-degrading bacterium isolated from a herbicide-contaminated soil. Antonie van Leeuwenhoek, 112(10): 1523-1532. 